Imperial Russia and the Struggle for Latin American Independence, 1808-1828 
THIS PAGE INTENTIONALLY LEFT BLANK 
Latin American Monographs, No. 43 Institute of Latin American Studies

The University of Texas at Austin 


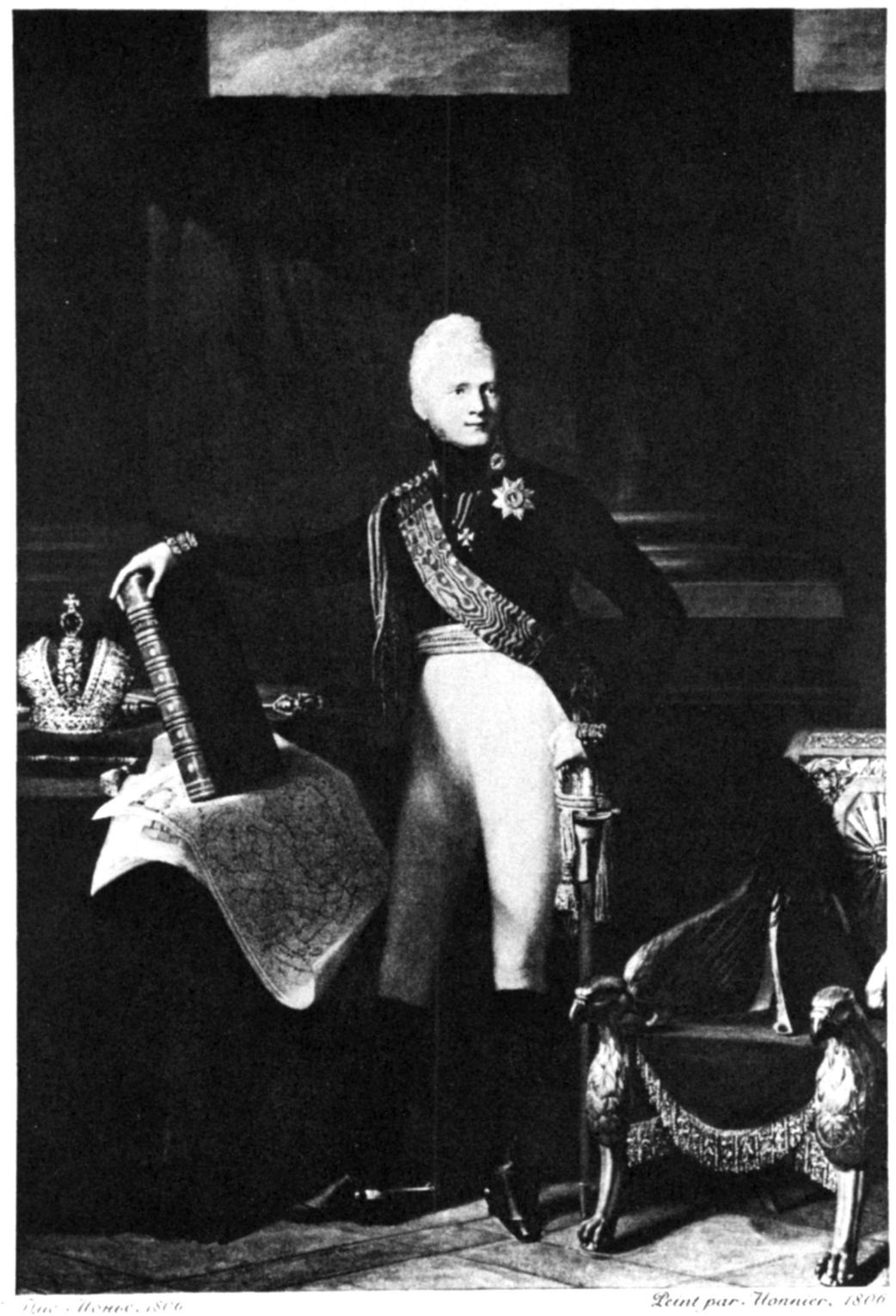

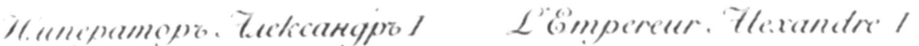




\section{Imperial Russia and the Struggle for Latin American Independence, 1808-1828}

Russell H. Bartley

Institute of Latin American Studies

The University of Texas at Austin 
International Standard Book Number 0-292-73811-0 (cloth)

0-292-73812-9 (paper)

Library of Congress Catalog Card Number 77-89770

Copyright (C) 1978 by Russell H. Bartley

All rights reserved

Printed in the United States of America

The Latin American Monographs Series is distributed for the Institute of Latin American Studies by:

University of Texas Press

P. O. Box 7819

Austin, Texas 78712 
In cherished memory of my father and for Mary, who shares that memory 
THIS PAGE INTENTIONALLY LEFT BLANK 